\title{
THE ROLE OF THE INTELLECTUAL CAPITAL IN ACHIEVING COMPETITIVE ADVANTAGE: A COMPARATIVE STUDY BETWEEN PRIVATE UNIVERSITIES OF TURKEY AND UAE
}

\author{
NIMA ALFARRA \\ Al-Aqsa University, Gaza \\ Faculty of Business Administration \\ Palestine
}

\section{ABSTRACT}

This study aims to examine the reality of intellectual capital in the private universities of Turkey and UAE and the role of intellectual capital in enhancing their competitive advantage. In this regard, the study explores the extent to which each element of intellectual capital influences the competitive advantage of the universities under the study and whether there is a difference between universities in how to manage the intellectual capital that they own. Accordingly, the study first explains the definition of intellectual capital and its elements (human capital, structural capital, relational capital), as well as the definition of the competitive advantage and its dimensions and fields of achievement in the universities under the study. Besides, it also investigates the relationship between the administrative procedures followed by these universities in the management of intellectual capital and in enhancing their competitive advantage from several aspects (innovation, quality, flexibility, development, and quality of service). The study relied on the selection of a simple convenience sampling method of the population of private universities in Turkey and UAE by a descriptive analytical approach, so a survey was made to verify the approaches in the theoretical frameworks of the intellectual capital and its relation to the dependent variables, which is the competitive advantage. The hypotheses were tested based on statistical analysis programs. The statistical analysis points to several important results and implications. Findings of the study reveal that there is a statistically significant relationship between the ability of the private universities in Turkey and UAE to manage their intellectual capital and enhance their competitive advantage, while the management of human capital, structural capital, and relational capital seem to have a similar impact rate on the Turkish and UAE private universities in enhancing their competitive advantage. Findings of the study further indicates that there is no statistically significant difference in the average responses of sample members on the level of the availability of intellectual capital requirements and achievement of competitive advantage in the private universities in Turkey and UAE due to some variables like gender, age, qualifications, years of service, years of service in the current position, job title.

\section{Keywords: Intellectual Capital, Competitive Advantage, Private Universities, Turkey, UAE}

\section{Introduction}

Today, organizations are working in an age of rapid change, accumulation of knowledge, the proliferation of means of communication, and access to information. These changes and developments in the environment have resulted in a gradual shift from tangible resources to intangible resources, represented in human elements because they are responsible for all the activities and functions of the institution, which is the responsibility of the success and survival of the organization; Thus, we find the interest in human elements particularly in intellectual resources represented in intellectual capital as one of the most valuable assets that possess the capabilities and expertise, the source of innovation and renewal, the need to manage and maintain development, and the successful organizations which care about their customers, their needs, and desires. The main challenge for organizations today is to ensure that skilled and distinguished individuals are available and to train, maintain, and develop their skills in a way that supports the competitive position of the organization and provide it with a competitive advantage from the rest of the competitors and maintain its survival and continuity. Intellectual capital methods have become of a major rank in higher education institutions, whereas knowledge is their base output and input. Universities yield knowledge, either through technical and scientific researches (the results of the investigation, publications, etc.) or through teaching; 
Moreover, their most energetic resources include teachers, researchers, administration and service staff, university committees and students, with all their organizational relationships and daily routines.

It is the responsibility of the departments in the Turkish and UAE universities to help the university move forward, enabling it to keep abreast of the developments in the various fields of higher education on the one hand and to benefit from the resources it possesses and to provide the necessary means to achieve the desired progress. And made it a prestigious place among its competitors from other universities on the other hand. Higher education in both Turkish and UAE private universities has witnessed tremendous development over the past two decades, which has witnessed a great growth in the number of students enrolled in higher education institutions. This increase in the number of students led to the emergence of several institutions of higher education providing educational services in different ways and means, which increased competition between these universities, whether locally or globally.

The official statistics by Turkish Ministry of Education and Higher Education indicates that the number of students enrolled in private Turkish universities for 20112012 was realized as 240,107, while the statistics registered with the Ministry of Education shows that 569,026 students registered in the private Turkish universities in 20162017. But the official statistics recorded in the UAE Ministry of Education and Higher Education indicate that 5,814 students graduated from private universities in 2013-2014, an increase of $166.9 \%$ in the number of graduates compared to the previous years (2008-2009) (Abu Dhabi Statistical center,2015). This is reflected in the development of education as well as the emergence of new educational institutions, each seeking to develop itself and reserve a place among local and international universities, and try to achieve further progress and development, as evidenced by the statistics of the high turnout to join universities in the recent period. And from here it set out the idea of interest in the intellectual capital and its initiatives in the Turkish and UAE private universities which were launched to help them achieve the desired excellence. Against this background, this study aims to explore the role of intellectual capital in achieving.

\section{LITERATURE REVIEW}

\subsection{Intellectual Capital (IC)}

This concept emerged in the 1990s and became the true wealth of a competing and successful organization rather than a material resource. Yet, this does not mean that the concept of intellectual capital did not exist before the 1990s, what we mean is that it was not under consideration; it was known as "shop fame" and contains all the intangible assets of the organization and appears in its budget (Sullivan, 2001: 23). Moreover, Al-Anzi and Saleh (2009) identify three stages which paved the way for the emergence of intellectual capital and contributed to the development of its concept, which is as follow early trends of attention to human capabilities, conceptual hints and trends of mental competence, and intensifying research efforts and the birth of the theory.

There were many definitions of intellectual capital set by academics and researchers; they were defined from different perspectives; academic, administrative, economic and other. Hamel and Heene (1994:19) were among the first scholars to explain that the intellectual capital is a unique ability that the organization excels over its competitors to achieve integration in the different skills that individuals possess, and which contribute to increasing the value offered to buyers; it is a source of a competitive advantage. Four years later, Ulrich (1998:02) defined it as a set of skills available in the organization that has a broad knowledge that makes it capable of making the enterprise global by responding to customer's requirements and opportunities to be produced by technology. Later, Bontis (2001:45) defined the intellectual capital as "the sum of everything that everyone in the organization knows and achieves a competitive edge in the market. Wall et al (2003:15) defined the Intellectual capital as intellectual material that has been formalized captured and leveraged to produce a higher-valued asset. While Stewart (2010), defined intellectual capital as the intellectual material knowledge, information, intellectual property, experience - that can be set to use to create wealth, Ousama et al (2014) defined intellectual capital as intangible sources that include knowledge, experience, management philosophy, intangible assets and human resources, which are used to help create and increase the value of the company and the economic knowledge that lead organizations to rely on intellectual capital to achieve their objectives. 
Important underlying concepts in these definitions include the notion that intellectual capital is the result of the interaction between all the intangible assets of the organizations which include the competence, expertise, and skill of the employees of the organization, the external relations and customers it possesses, and the organizational structure it possesses. All of which help the institution to expand and improve its market share and enhance its competitiveness in the market, and not to focus intellectual capital at a particular managerial level.

A group of researchers presented many divisions of the components of intellectual capital, which agree in their components but differ in the method of division, some of them divided into two, other into three, and into four or more components. In this paper, the researcher adopted the division on which most researchers relied, which is that the intellectual capital consists of three main elements: human capital (skills and expertise), structural capital (intellectual property, software, and documents) and relational capital (relation with customer and suppliers).

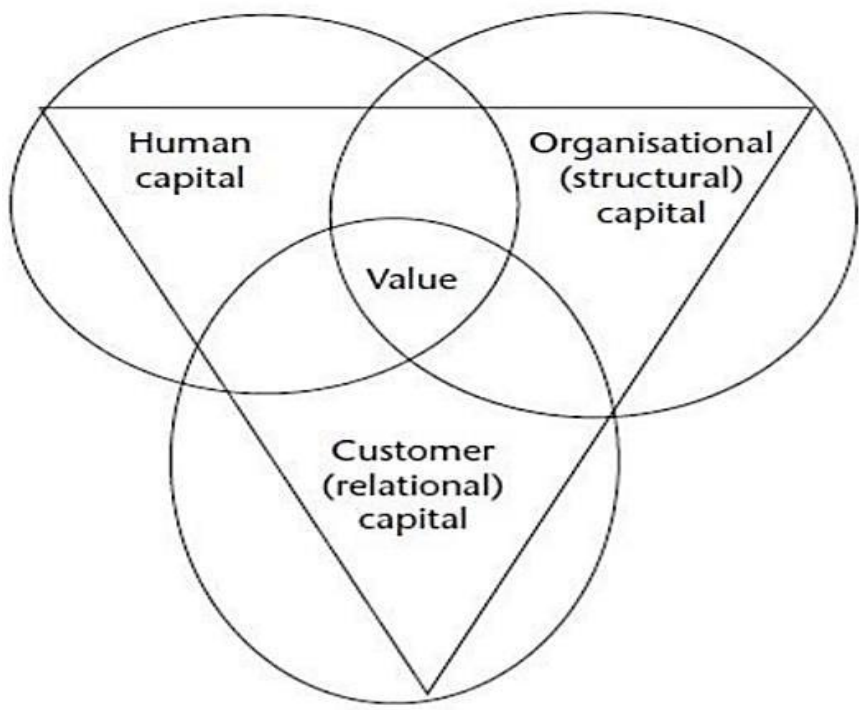

Figure 1.1: The Main Components of Intellectual Capital Source: (Wall et al., 2003)

\subsubsection{Human Capital}

Presumably, the biggest evolution in the economics of education in the past 30 years has been revolving around the idea that of physical capital, as embodied in tools, machines, and other production equipment, as well as human capital (Schultz 1961; Becker 1964). Coleman (1988) mentioned how it was created by changes in individuals that bring about skills and capabilities that make them able to act in new ways. Similarly, Florin and Schultze (2000) defined Human Capital as the skills and capabilities of people that constitute an important source of competition for individuals, organizations, and communities. While Luthans et al (2004: 45-50) defined the concept of human capital as the individuals working at all standers of the institution and the economic capital as the resources withdrawn from consumption that are invested for future expected return, Nedjema (2016: 30-57) argued that human capital is composed of creativity, professional competence, and social compete.

\subsubsection{Structural Capital}

Structural Capital arises from human capital as a mixture of knowledge and intangible assets resulting from the processes within the institution as well as encompasses elements of efficiency, procedural innovativeness, and access to information for codification into knowledge (Edvinsson, L., Malone, M. S., 2001: 149). Also, it is the backing of infrastructure that companies tool up to their human capital (Sullivan, 1998: 23). Meanwhile, Fazlagić and Erkol (2017:184), Stewart (2007,2010), Huysman and Wit (2002), Köper and Zaremba (2000), and Guthrie and Petty (2000: 241-251) included in the definition of Structural Capital systems and work processes that involve quality and access of information technology systems, company images, hardware, software, database, organizational structure, patents, documents, trademarks, and other codified knowledge. The 
structural capital is composed of the knowledge Transfer' Process and Procedure of Innovation' Knowledge Management' and Corporate Culture (Cabezas, R., 2014: 42).

\subsubsection{Relational Capital}

The main theme of relationship capital is knowledge of market channels and of customer and supplier relationship as well as a sound understanding of government or industry association impacts (Choo, Bontis, 2002:632). In contrast, Ordoñez and Edvinsson (2015) defined the relational capital as the sum of the organization's relations with customers, suppliers, partners, and the public. According to Viedamand and Cabrita (2012), the relational capital is knowledge entrenched in the relationships with any investor that effects on the institution's life. Partially agreeing with their definition is Fazlagi (2017:184) who described it as the knowledge entrenched in the relationships of an institution with its customers, suppliers, strategic alliance partners, and stakeholders. The relational capital is composed of the external: customer (relational) capital as brands, clients, client loyalty, firms' names, distribution channels, commercial collaborations, licensing contracts, favorable agreements, franchising contracts (Guthrie, J., 2001:24-41).

\subsubsection{Principles of Intellectual Capital Management}

Intellectual Capital Management is an advanced administrative field that dates back to the mid-1980's and was developed by the influential publications of Prof. Davied Teece, which draws value from creativity. Meantime. Since then, the motivation, new ideas, and innovations in this field have been developed by companies that manage intellectual capital. The intellectual capital field has developed in two distinct aspects of focus: value generation (Sullivan, 1998: 22). The management of intellectual capital is known as the procedure of extracting the value of knowledge, which can produce profit for the institution. Then, it is believed that information could provide institutions with profits and smooth their management (Osinski et al., 2017: 480-481).

\subsubsection{Measurement of Intellectual Capital}

The objective of measuring intellectual capital is to identify the usefulness of the capital investments spent by the Organization in the areas of human development, structural development, and the acquisition of customers in order to maintain excellence compared to competitors in the long term (Jadalrab and Sayed, 2006). Roos, et al, (2001) pointed to the need to build an effective model for measuring intellectual capital, and the success of this model is achieved if it includes both financial indicators and non-financial indicators together, reflecting the Organization's operations under the effects of the knowledge economy. In addition, the measurement methods of intellectual capital is involved in the literature of management and accounting and its various models: descriptive models, measures and models related to the measurement of components of intellectual capital, market value measurements and models, and models and Methods of Return on Knowledge (Najm, 2016: 222-226). There are many errors associated with measuring intellectual capital such as the measurement process is not linked to a strategy, non-activation of links between causes and results, lack of setting good goals for performance, wrong measurement (Inter and Larcker, 2003).

\subsubsection{Intellectual Capital in Institutions of Higher Education (Universities)}

The university is on the top of the pyramid in the education system around the world and is the cornerstone of sustainable human development, especially in the present age, where the university is one of the social educational institutions that have become the focus of many different fields. For this educational institution to achieve a real development of the intellectual capital, on a scientific basis, educators must adopt advanced strategies in education and training. They should focus on the cognitive processes required by intellectual development plans and employ modern technologies in an effective manner to achieve the desired results in the management, measurement, and development of intellectual capital (Hilali, 2011: 4).

\subsubsection{The Role of Universities in the Knowledge-Based Society}

Knowledge societies are aptitudes of identification, production, dispensation, transformation, distribution, as well as use the information to build and apply knowledge for human development. They need a certified social vision 
that holds plurality, inclusion, solidarity, and contribution (UNESCO, 2003). As knowledge can be shaped, engrossed, and applied just by the educated mind, schools in general, and universities, in particular, are going to play progressively energetic roles as societies enter this new era. Knowledge is the medium of the university through the activities of discovery, shaping, achieving, transmitting, and applying knowledge. The university serves society in many ways: educating the young, preserving our cultural heritage, providing the basic research so essential to our security and well-being, training our professionals, and accrediting their competence, stimulating our society and inspiring social change (Duderstadt, 2002).

\subsection{Competitive Advantage}

The competitive advantage is a very important strategic element in providing an essential opportunity for the organization to achieve continuous profitability compared to its competitors. First to propose a definition was (Porter, 1993: 48) who said: The competitive advantage is that "the new methods discovered by the institution, which are more effective than those used by competitors so that they can apply this discovery on the ground. Later on, Lambin (1998) defined the competitive advantage as the sum of characteristics or attributes that characterize the product or mark, which gives the organization some superiority over its immediate competitors. Generally, it is the process of finding or creating a system that has a unique and distinct advantage that is superior to that of competitors and that the idea focuses on creating value that is provided to the customer in an efficient way (Heizer and Render, 2008). Moreover, David (2009), defined it as the ability of the organization to apply new production processes that have not been applied in competing organizations, mainly when these organizations cannot obtain the resources to imitate those processes. Thoroughly, competitive advantage can be defined as the ability of the organization to acquire a set of characteristics and the elements through which it can achieve progress and superiority over other organizations operating in the same field. Accordingly, it represents the strength point distinguishing the organization from its competitors.

\subsubsection{The Sources of Competitive Advantage}

Porter (1985) provides three key sources of competitive advantage: cost Leadership Strategy, Differentiation Strategy, and Focus Strategy. These sources are key themes for Porter in designing his competitive strategies, applied in business organizations according to surrounding environmental conditions. For Grant (1991: 119), the sources of competitive advantage are achieved through unique skills that include technical, managerial and functional skills, as well as resources owned by the organization, such as distribution networks, production capacity, marketing power, and technology. Also, the tangible and intangible resources are important sources of competitive advantage to ensure the success of the competitive advantage, there is a need for high resources and competencies, since competition is not limited to the development of competitive strategies, but it is extended to research and development on an ongoing basis, relying on resources and competencies. According to (Bushnav, 2002: 48-49), these resources are divided firstly into tangible resources as primary resources, production equipment, and financial resources, secondly into intangible resources such as quality and technology.

\subsubsection{The Basic Factors of Building the Competitive Advantage}

Hill and Jones (1989: 113) identify the four factors that build competitive advantage: efficiency, quality, innovation, customer's responsiveness as in figure (2.2). 


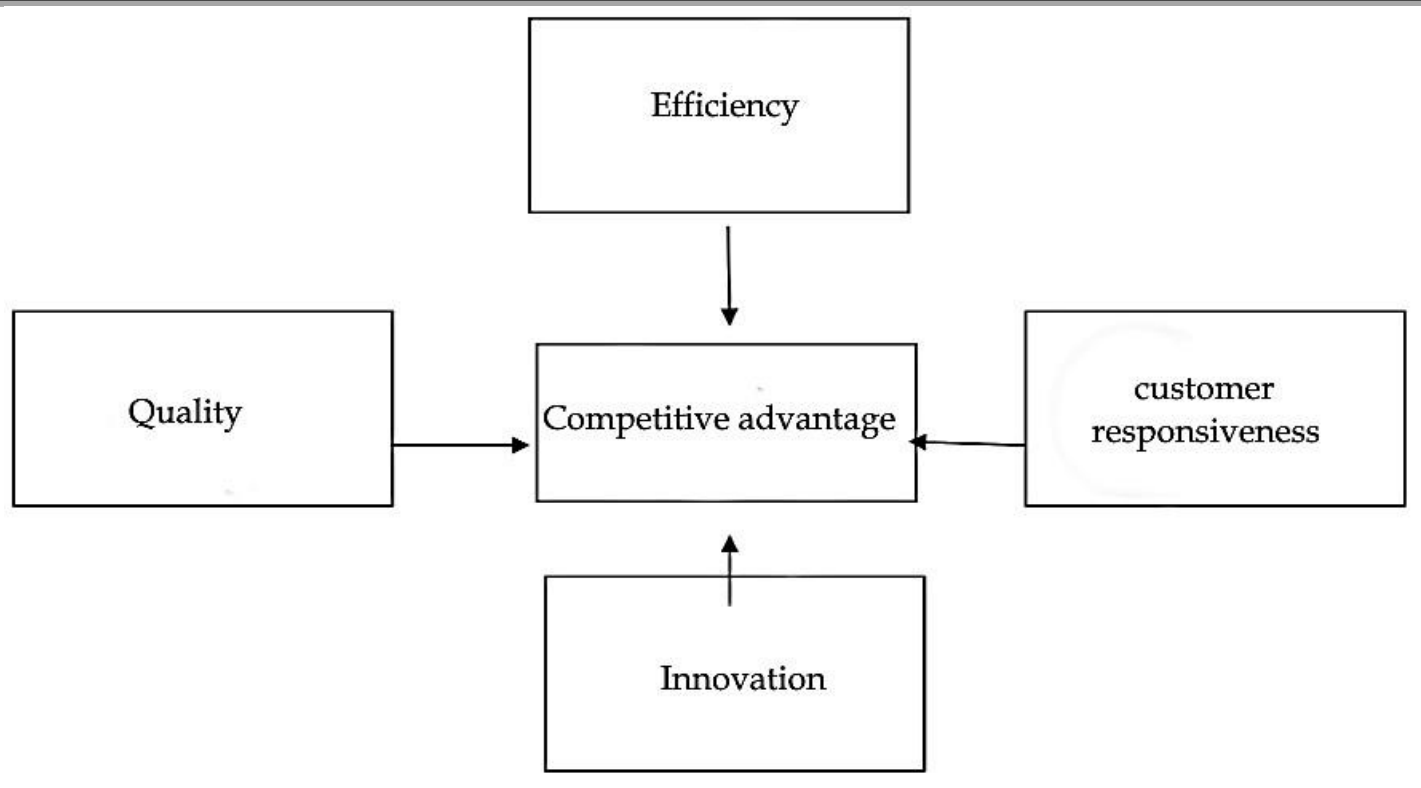

Figure 2.2: Competitive advantage building factors Sours: Hill and Jones, (1989: 113)

Any company can adopt factors regardless of their industry or products or services provided by all these elements integrated with each other. Hill and Jones (2010) explain to them as follows:

\section{Efficiency}

Efficiency can be measured by the amount of input that the company needs to produce a product. The more efficient a company is, the fewer the inputs required to produce a given output and the lower its cost structure will be. The company has efficiency when its production is high and at lower costs than its competitors.

\section{Quality}

The concept of quality is associated with the reliability and excellence of products. The high quality gives the company many advantages, including the good reputation that allows the company to provide products that vary remarkably from its competitors' and therefore create customer responsiveness, which gives the company the chance to increase the prices for its products. Also, it means eliminating defects and errors that occur in the production process, reducing waste, increasing efficiency, and lowering the cost structure of the company in order to increase its profitability.

\section{Innovation}

Innovation is one of the most important factors of competitive advantage. It leads to new products that aim to better satisfy customer needs by improving quality or reducing cost, and because competitors are always trying to imitate successful innovations and often succeed, so if the company seeks to maintain the competitive advantage, it must have a continuing commitment to innovation.

\section{Customer Responsiveness}

Responding to customers is a special and important feature provided by any company because it helps build brand loyalty and strong product differentiation. This benefits the company by giving it more pricing choices. A firm that is more receptive to the needs of its customers than its competitors will have a competitive advantage and can get the response of customers by giving them what they want. To achieve superior responsiveness to customers, the firm has to listen to its customers, explore their needs and identify them and need to pursue better ways to satisfy those needs continuously.

\subsubsection{The Relationship between Intellectual Capital and Competitive Advantage}

Many studies have attempted to link intellectual capital and competitive advantage in terms of standards and outcomes. Stewart (1999: 3) explained that intellectual resources are the most important resources of the institution 
and that the investment of mental capacity and the promotion and effective management of intellectual capacity achieve intellectual performance. All of which can lead to competitive excellence through the transformation of the abandoned value available in the minds of the employees of the institution and the loyalty of customers and systems and collective knowledge.

Stewart (1996: 2) considers that the true value of the enterprise lies in its intellectual capital and ability to employ the knowledge inherent in it and turn it into applications that achieve high performance and thereby improve its competitiveness. Yet, Beatty (1996:2) pointed out that in the analysis of competitive intellectual capital through strategic management of performance, the productivity of intellectual assets was the focus of the institution's work and the basis of its success. Thus, the effective investment of intellectual capital is the main determinant of the supremacy of competencies, especially if the organization can attract specific competencies.

\subsubsection{Competitive Advantage in Universities}

Issues such as change, competition, accountability, the combination of laboratory and field research on the one hand and applied research on the other hand, the development of strategic alliances, dealing with learners rather than students, lifelong learning as a new definition of continuing education, effective response to university stakeholders, among other issues have had a significant impact on the survival of these institutions (Rowley, 2004).

The competitiveness of the academic institution depends on two main areas. First, the ability of excellence in competing universities in vital fields. Second, the university's ability to attract students, support and funding from local and overseas markets. The success of the second part depends on the success of the first part. Therefore, the competitive context of higher education calls on the institutions of higher education to exert efforts in defining the beneficiaries of their activities and services, as well as distributing them to target slices and groups so that they can work on their needs and desires and try to satisfy it to achieve their goals and aspirations in the future (Suarez, 2006: 314).

\section{Method}

\subsection{Research Design and Data Collection}

The questionnaire was validated by a group of experts, academics, and specialists. Data were collected from the deans, assistant deans, head of the departments in Turkey and UAE private universities. The study relied on the selection of a Random of a sample. The number of individuals who cooperated with the study and responded to the research application form 140 individuals; 70 individuals were from private Turkish universities, and 70 individuals were from UAE universities.

\subsection{Measurement}

Study tool is represented in a form of a questionnaire, which consists of two main sections, the first section represents personal information researched and specified by gender, age, academic achievement and the total number of years of service and in the current position. While the second section representing the axes of study, intellectual capital consists of three parts: human capital (skills and expertise), structural capital (intellectual property, software, and documents) and relationship capital (relation with customer and suppliers) and the competitive advantage depend on four dimensions as high efficiency, high quality, high innovation, and high customer responsiveness. Questionnaire has been designed according to five Likert scales, where answers are given numerical weights that present the answer degree to every statement, so it would be as follows, $($ Strongly agree $)=5,($ Agree $)=4,($ Neutral $)=3,($ Disagree $)=2$, $($ Strongly disagree $)=1$.

\subsection{Data Analysis and Results}

$77.1 \%$ of the respondents in privet universities in Turkey were male as well as the females were $22.9 \%$. In addition, about $42.9 \%$ of the respondents fall within the of 50 years and more, also roughly $90.0 \%$ had Ph.D. degrees. Meanwhile, the work experience of about $55.7 \%$ of the respondents ranges from 15 years and more. While the male in UAE privet universities were $56.7 \%$ and the females were $34.4 \%$. Furthermore, $41.4 \%$ of the respondents fall within the of 30-40 years, and 58.6\% had Ph.D. degrees. At the same time, the work experience of about $37.1 \%$ of the respondents ranges from 15 years and more. The properties according to their personal data are explained in Figure 1. 


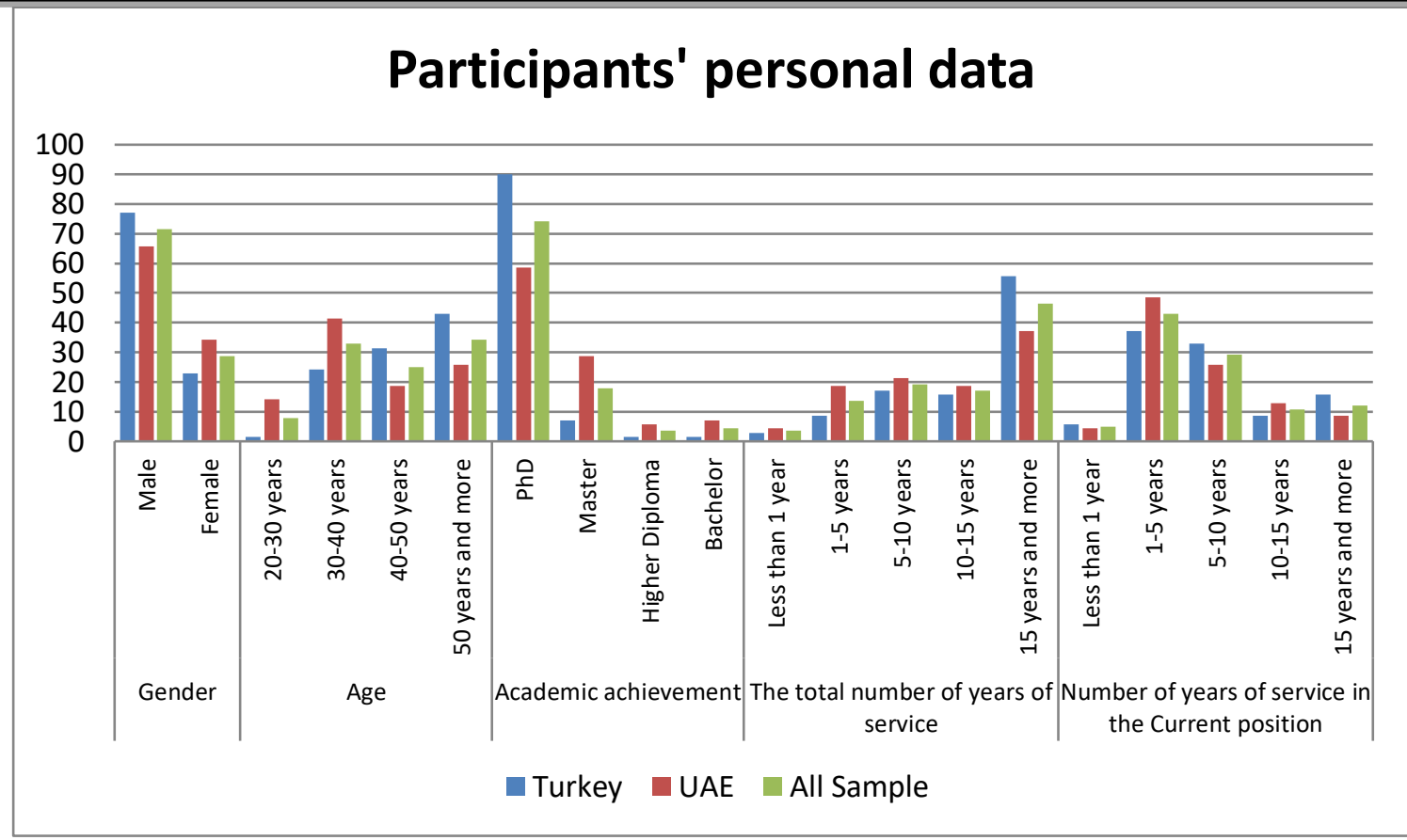

Figure 4.1: Properties according to their personal data 5.1 Assessment of Measurement Model

The results indicate validity consistency of internal data in the study where values of correlation coefficient ranged for all phrases in all study axes between 0.541 to 0.886 , and these values were significant at the $1 \%$ level.

\section{The Results of Intellectual Capital \\ 1-Human Capital}

The results in private universities of Turkey and UAE indicated that there is agreement by the respondents on all the phrases of this axis and through this result, we found that the UAE private universities achieved the highest rate in the human capital (3.47) with relative weight (69.21). The phrase "The teachers at the university characterized by possessing high levels of knowledge." was ranked first with relative weight $74.86 \%$, helping to gain quality in competitive advantage areas, while the phrase "The university is keen to maintain teachers with diverse knowledge" was ranked first in the private universities of Turkey with relative weight $74.57 \%$ by maintaining them and preventing them from leaking to competitors or depriving them of their services, which helps in gaining quality in performance in the areas of competitive advantage, and the phrase.

As we as the phrase " The teachers at the university characterized by possessing high levels of knowledge", was ranked second in the private universities of UAE with a relative weight of $72.00 \%$. This is evidence of the university's knowledge of the importance of possessing teachers with high knowledge and experience, believing that this represents the most important pillars of the competition, and the belief that teachers with high knowledge have a key role in their development and that they must keep them from leakage and transfer their experiences to competitors, which may affect their positions between universities, while the phrase "The University offers training programs and development of human cadres which reflects on their performance" were ranked second in the private universities of Turkey with relative weight $68.86 \%$. This indicates that the development and creativity of the human cadres are increased by increasing the scientific, training and research achievements, as this has implications for the university's name, reputation, and places among the universities. This is done only by the university administration and providing the necessary manpower to produce its creative and research capabilities. Creativity contributes greatly to the improvement and development of scientific and practical level within the university. 
While the phrase "The University rewards the creators of academic and administrative work according to specific and clear program" was the last order in the private universities of Turkey with a relative weight of $64.57 \%$ and in private universities of UAE with a relative weight of $66.29 \%$. Where the existence of a clear program to reward creators creates a spirit of competition and discipline and creativity at work, and therefore it will reflect on the nature and quality of services provided by employees and the university, and may be due to the absence of what shows keenness Universities to reward the creators and the absence of incentive programs, which may be caused by the conditions surrounding the universities and the lack of care that exists among decision-makers in universities to follow the creators and motivate them because of great concern in the performance of their duties.

\section{2- Structural Capital}

The results in private universities of Turkey and UAE indicated that there is agreement by the respondents on all the phrases of this axis and through this result, we found that the private universities of Turkey achieved the highest rate in the structural capital (3.60) with the relative weight of $71.96 \%$. The phrase "The University considers that the administrative structure it possesses is one of the most important pillars of competition and excellence achieved by its competitors from universities" was ranked first in private universities of Turkey with relative weight $77.43 \%$, and $75.43 \%$ in private universities of UAE, which mean that the development of the administrative structure owned by the private universities in both countries has recorded the highest percentage in supporting the competitive advantage of the universities. This is achieved through the universities' keenness on quality in providing their scientific and research services. As well as the development of the administrative structure of universities, which helps facilitate communication between all levels of management reflects the development and quality in the provision of services to the University in support of them in enhancing their competitive advantages.

As well as the phrases "The University's structure helps employees provide outstanding services to students and local community", was ranked second in the private universities of Turkey with relative weight $72.94 \%$. Provide outstanding services to both students and the local community is an important advantage and one of the most important aspects of attracting and distinguishing the university from others, and the phrase "The University provides all the means that allow employees to access the University's regulations and information and services that she presents." was ranked second in the private universities of UAE with relative weight $74.29 \%$, while it was the last order in the private universities of Turkey with relative a weight of $69.43 \%$. This shows that UAE private universities are seeking more to increase the efficiency of its staff by providing mechanisms that help to raise the overall performance and harness the structure of their service and disseminate the information they may need through the development of data that may be necessary. Which reflects the evolution of management and transparency practiced through the advanced management methods it uses.

The phrase "The University has a well-publicized administrative structure that helps to deliver its services distinctly from others" was the last order private universities of UAE with a relative weight of $67.14 \%$. The administrative structure is one of the most important pillars of the university, and attention to its modernization and development helps in the development of the administrative process and serves it greatly. Which is one of the most important aspects of university excellence and helps in applying the structure of the university in the desired manner. However, administrative policies adopted by the university may prevent continuous development, making it one of the least administrative procedures used in the structural development of universities.

\section{Relational Capital}

The results in private universities of Turkey and UAE indicated that there is agreement by the study members on all the phrases of this axis, the UAE private universities achieved the highest rate in the relational capital (3.65) with relative weight $72.93 \%$.

The phrase " The University cares about the opinions of its customers and takes their observations seriously" was ranked first in private universities of UAE with relative weight $76.57 \%$, and this shows that the universities allocate human and financial staff for this matter. Which in turn can contribute to improving the quality of the services it provides as well as achieving quality in the provision of its services, while the phrase " The University has extensive scientific and research relations with research and consulting centers, which enhance the university's 
reputation and its ability to innovate" was ranked first in private universities of Turkey with relative weight $74.00 \%$ which enhance the university's reputation and its ability to innovate, as well as has a profound impact on how the bright image of the university to others.

The phrase "The University is interested in developing relations with universities and other scientific bodies" was ranked second in private universities of Turkey and UAE with relative weight $73.43 \%$ second in private universities of Turkey, and $74.86 \%$ in private universities of UAE .The good relationship between the university and universities and other scientific bodies reflects the degree of discipline and respect that the university has, which in turn helps to raise the reputation and prestige of the university.

While the phrase "The University has a clear policy to develop its relationship and reputation with clients who deal with the University" was the last order in both countries private universities with a relative weight of $68.86 \%$ in the private university of Turkey and $68.29 \%$ in the private university of UAE. The University's keenness to continuously communicate with customers and open the way to develop relations with them to communicate their good image to them and to impose the name and reputation of the university to the customers, which helps to enhance the competitive advantages that it possesses significantly. The university may consider this difficult because of the diversity and multiplicity of relationships with clients and the required allocation of financial and human cadres, which increases the burden of the university.

\section{The Results of Competitive Advantage}

Based on the results we can arrange the dimensions of the competitive advantage in terms of importance as follows:

\section{Quality}

The quality came in the first ranking in the private Turkish universities while the third rank in the UAE private universities. This indicates that the private Turkish universities are concerned about the quality of human resources, the quality of the academic programs and their ability to respond to the changes and rapid developments surrounding them.

\section{Creativity}

The creativity ranked first in private universities in the UAE, while it ranked third in private Turkish universities in terms of relative importance given to from the sample. This shows that private universities in the UAE give greater importance to creativity by encouraging teachers to take initiatives to improve educational services in a way that distinguishes them from other universities, adopting new technology in their educational and administrative processes, and seeking to gain competitive advantage through expansion of innovation, innovative use of modern methods in the implementation of training programs.

\section{Efficiency}

The efficiency ranked last in the Turkish and UAE private universities. This reflects the lack of sufficient attention from the universities to provide material or moral resources that will support the efficiency and excellence in work, whether by the human cadres by providing material or moral incentives on the one hand, or through the provision of infrastructure and the provision of the necessary equipment and devices that support efficiency, The development and quality of performance, which involve under the administrative procedures of human capital and structural capital, may be attributed to the high cost required by the required support, as well as the absence of clear policy in the universities reward creativity and excellence

\section{Responsiveness}

The response ranked second in the private universities of Turkey and the United Arab Emirates. It is one of the elements of achieving the competitive advantage resulting from the development of the systems used. It reflects the flexibility in the university's structure and its ability to adapt to the modern technological revolution and its 
@Center for Promoting Education and Research (CPER) USA, www.cpernet.org

keenness to precede its competitors through its ability to respond quickly and adapt to providing a variety of services for their customers to meet their needs and desires.

\section{Results of the Proposed Hypotheses:}

First Hypothesis:

\begin{tabular}{|l|c|c|c|c|c|}
\hline \multirow{2}{*}{ H no } & \multicolumn{2}{|c|}{ Turkey } & \multicolumn{2}{c|}{ UAE } & Decision \\
\cline { 2 - 6 } & $\begin{array}{c}\text { Corr. } \\
\text { Coefficient }\end{array}$ & Sig. & $\begin{array}{c}\text { Corr. } \\
\text { Coefficient }\end{array}$ & Sig. & Supported** \\
\hline H1 & $0.909^{* *}$ & 0.000 & $0.911^{* *}$ & 0.000 & Supported $* *$ \\
\hline Ha1 & $0.729^{* *}$ & 0.000 & $0.644^{* *}$ & 0.000 & Supported** \\
\hline Hb2 & $0.828^{* *}$ & 0.000 & $0.662^{* *}$ & 0.000 & Supported $* *$ \\
\hline Hc3 & $0.809^{* *}$ & 0.000 & $0.721^{* *}$ & 0.000 & Supported $* *$ \\
\hline
\end{tabular}

Significant at $\mathrm{P}^{* *}=<0.01 \mathrm{P}^{* *}<0.05$

\begin{tabular}{|c|c|c|c|c|l|}
\hline \multirow{2}{*}{ H no } & \multicolumn{2}{|c|}{ Turkey } & \multicolumn{2}{c|}{ UAE } & Decision \\
\cline { 2 - 6 } & T-test & P-value & T-test & P-value & \\
\hline $\mathrm{H} 2 \mathrm{a}$ & 1.188 & .239 & .799 & .427 & Rejected \\
\hline $\mathrm{H} 2 \mathrm{~b}$ & 1.891 & .140 & .838 & .478 & Rejected \\
\hline $\mathrm{H} 2 \mathrm{C}$ & 1.569 & .205 & .424 & .736 & Rejected \\
\hline $\mathrm{H} 2 \mathrm{~d}$ & 1.298 & .280 & .717 & .584 & Rejected \\
\hline $\mathrm{H} 2 \mathrm{e}$ & 1.487 & .216 & 1.537 & .202 & \\
\hline
\end{tabular}

\section{Discussion and Recommendation}

In this study, we investigated the effects of the components of the intellectual capital (human capital, structural capital, relational capital), which will help the university to enhance its competitive advantages with its 
different dimensions (quality, efficiency, creativity, and responsiveness). We tested the hypotheses developed using data collected from private universities in Turkey and UAE. In summary, we showed that intellectual capital positively affects competitive advantage. In other words, we concluded that there is a relationship between the ability of the private universities in Turkey and UAE to manage their intellectual capital including (human capital, structural capital, and relational capital) and enhance their competitive advantage. On the other hand, we found that, there are no statistical differences in the average responses of sample members on the level of availability of intellectual capital requirements and achievement of competitive advantage in the private universities in Turkey and UAE due to some variables like gender, age, qualifications, years of experience, job title. Furthermore, the management of Human capital has a similar impact rate on the Turkish and UAE private universities in enhancing their competitive advantage. This shows the universities' knowledge of the importance of human capital and the importance of developing and maintaining it. As well, the management of structural capital has an impact rate that closely resembles the Turkish and UAE private universities in enhancing their competitive advantage. This shows the interest of the universities in supporting and developing the administrative structure that distinguishes them from other universities. Also, the management of the relational capital has an almost similar impact rate in the Turkish and UAE private universities in enhancing their competitive advantage. This indicates the strength of their relationships with their customers, and the keenness of universities to communicate their developments and what they offer to the community and its clients, and their great interest in announcing of local and international successes and achievements.

Based on the study, in order to enhance the ability of the university to compete with other national and international universities worldwide, certain suggestions may be recommended, which include the need to develop a clear program of the promotion mechanisms and assume administrative positions in the universities to open the way for employees with high competence to assume sensitive administrative positions on one hand, and reflect the extent of administrative transparency and to enhance the managerial trust of the employees on the other hand, and to instill the spirit of the competition and ambition among the employees to improve their careers. As well, support the University for Scientific Researches and Training Programs, and allocate annual material and moral returns to the distinguished scientific achievements, especially at the international level. And give attention to raising the efficiency of administrative and academic staff through the existence of a range of materials and moral incentives that will help in raising morals and fuel the spirit of the competition and diligence among the employees. Likewise, provide all the possibilities that aid the employees, students, and clients to obtain the information they need in carrying out their procedures or when conducting researches and studies, which in turn reflects a good image and high transparency of the university. Also, the universities have a continuous improvement in the structure of universities and support to the decision-makers, which will help facilitate communication between administrative structures in universities, which in turn will help improve the quality of services provided in the universities. As well as they need to take into account the suggestions of individuals and institutions cooperating with the University in accomplishing its work and providing its services, and this helps in improving the ways of providing services in a qualitative manner. In addition to considering the importance of strengthening relationships with clients because of their influence to reflect the bright image of the university to others. Moreover, strengthen relationships with clients and work to familiarize them with the university's scientific and practical services. 
International Journal of Humanities and Applied Social Science (IJHASS)

E-ISSN: 2471-7576

APRIL 2019, Vol: 4, Issue: 4

E-mail: editor@ijhassnet.com

http://ijhassnet.com/

DOI:10.33642/ijhass.v4n4p1

@Center for Promoting Education and Research (CPER) USA, www.cpernet.org

\section{A Proposed Plan to Implement the Researcher's Recommendations}

Figure (2.3) Shown the proposed plan to implement the researcher's recommendations about human capital management:

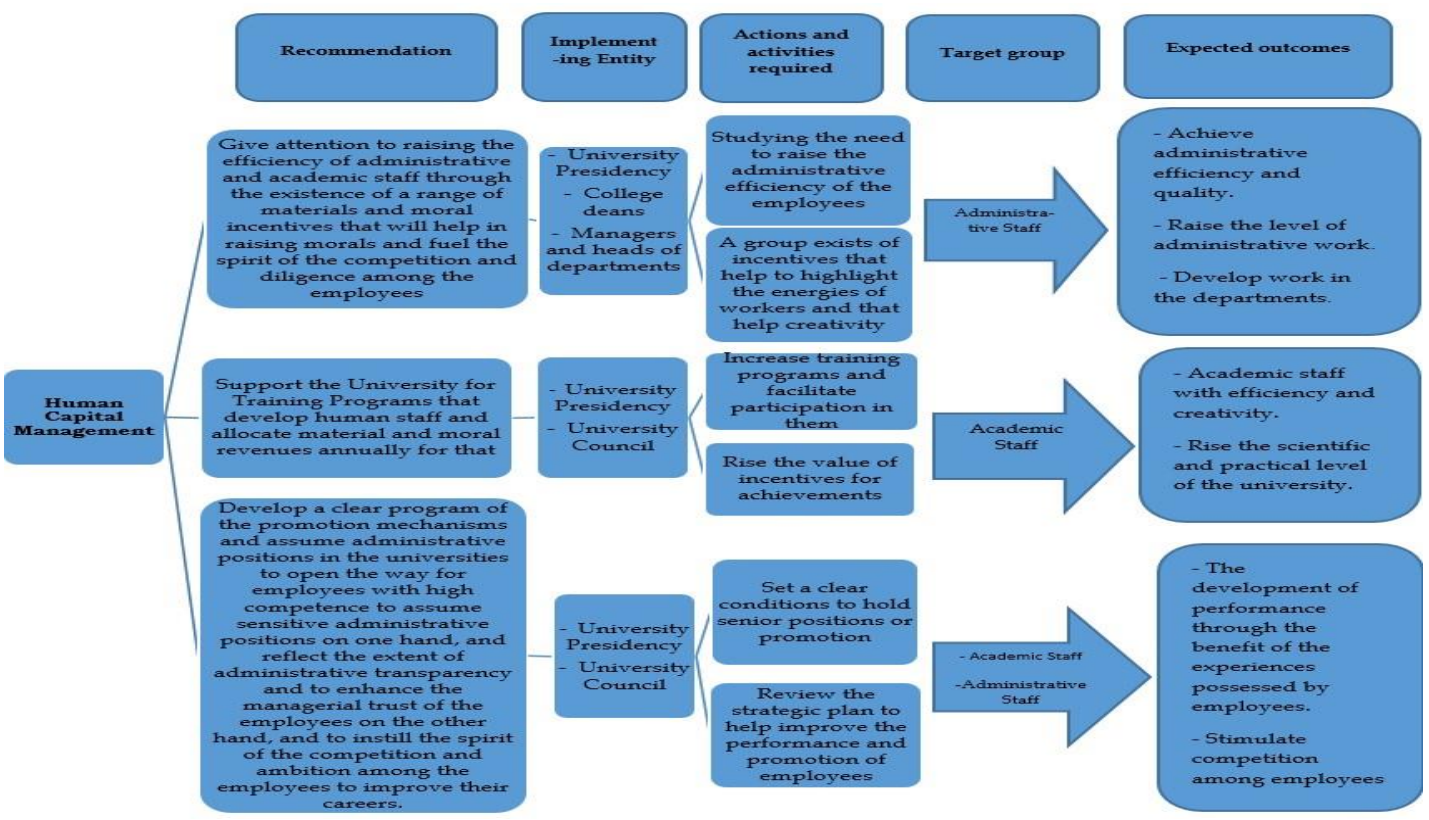

Figure 2.3: Human Capital Management

Figure (2.5) Shown the proposed plan to implement the researcher's recommendations about structural capital management:

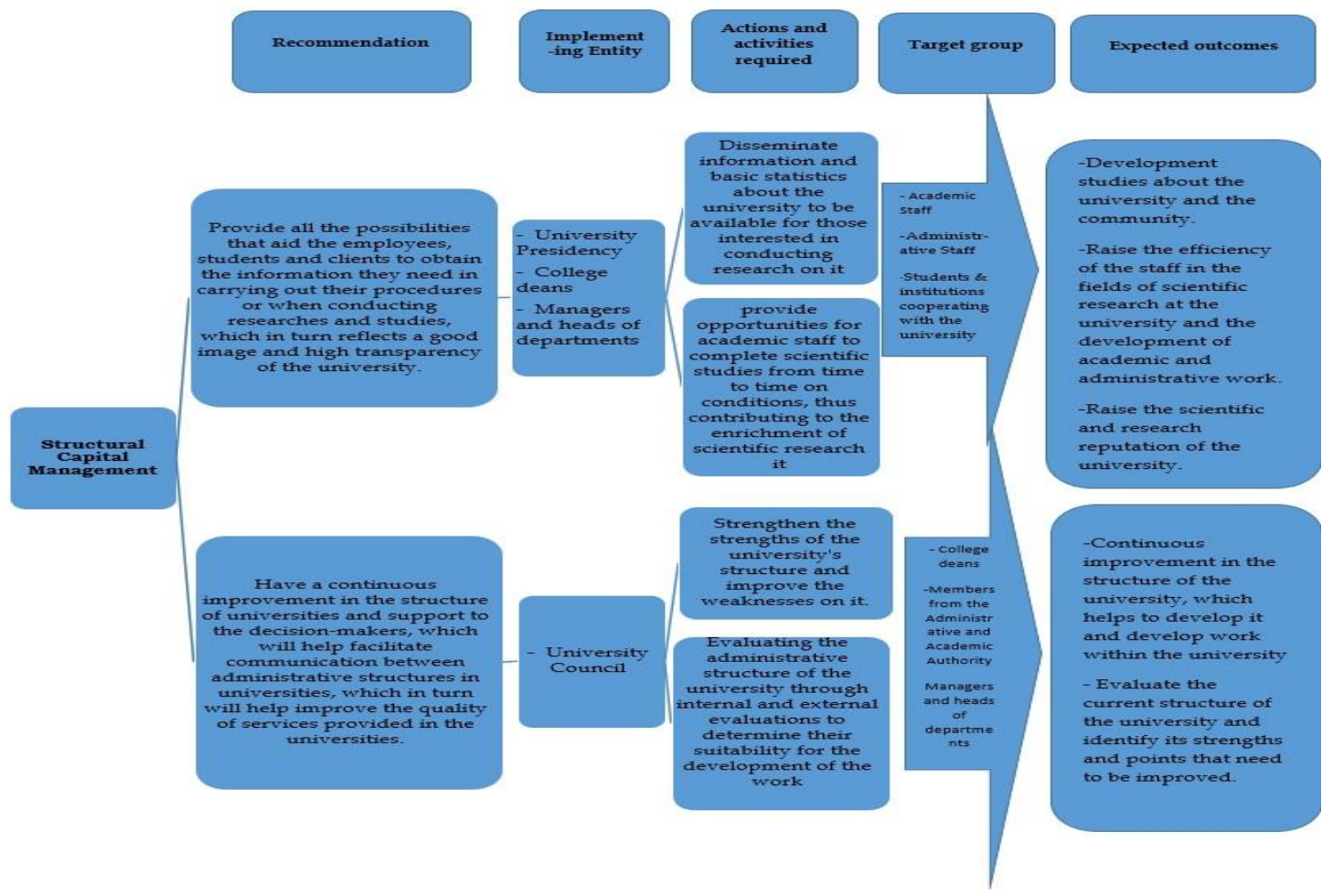

Figure 2.5: Structural Capital Management 
Figure (2.6) Shown the proposed plan to implement the researcher's recommendations about structural capital management:

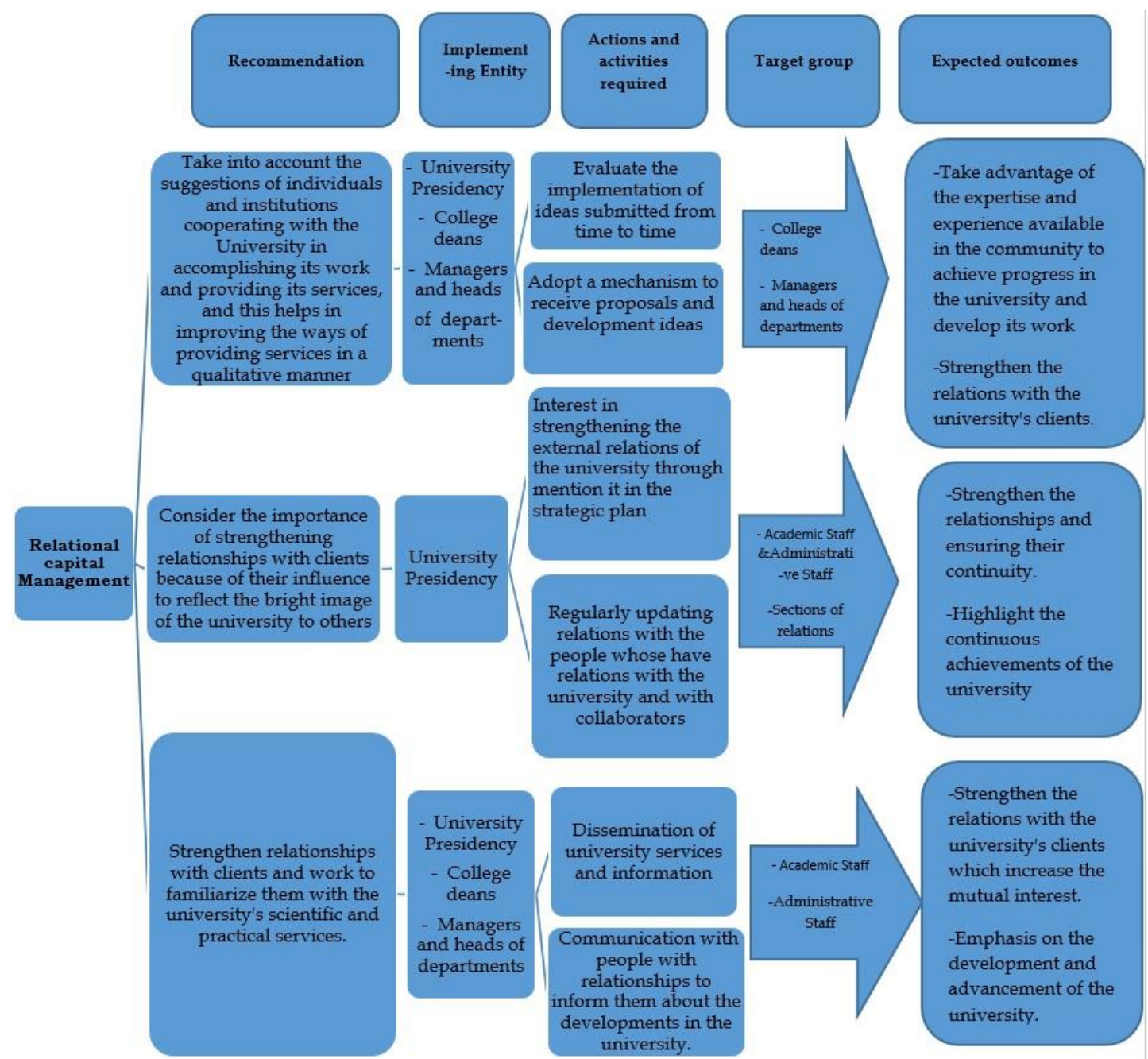

Figure 2.6: Relational Capital Management

\section{Reference}

Abu Dhabi Statistical Center (2015). "Discover Abu Dhabi through statistics," Abu Dhabi Statistical Center

Al-Anzi, Saad Ali, and Saleh, Ahmed Ali (2009). "Department of Intellectual Capital in Business Organizations." Dar Al-Yazuri Publishing and Distribution, Jordan, pp. 165-157

Beatty, Richard W., (1996). "Competitive human resource advantage through the strategic management of performance," Human Resource Planning, 12(3):179194.

Becker, Gary Stanley (1964). "Human capital: a theoretical and empirical analysis, with special reference to education," National Bureau of Economic Research; distributed by Columbia University Press.

Bontis, N. (2001). “Assessing Knowledge Assets: A Review of the Models Used to

Measure Intellectual Capital,” International Journal of Management Reviews, 3(1):41-60.

Bushnav, Ammar (2002). "Competitive advantage in the economic institution: its sources, growth, and development, " pp. 48-49, MA Thesis, University of Algiers 
Cabezas, R. (2014). "Opportunities and Diversification - Expansion of Business by Analyzing the Structural Capital of Engineering Service Firms.” Siplom.de

Choo, Chun W. and Nick Bontis (2000). "The strategic management of intellectual capital and organizational knowledge," New York: Oxford University Press.

Coleman, James S. (1988). "Social capital in the creation of human capital." American Journal of Sociology, 94: $95-$ 120.

David, Fred R. (2009). "Strategic Management: Concepts and Cases," Pearson International Edition, $12^{\text {th }}$ ed.

Duderstadt, J. (2002). "The future of higher education in the knowledge-driven, global economy of the $21^{\text {st }}$ century." Paper presented at the $175^{\text {th }}$-anniversary symposium of the University of Toronto; available at http://unesdoc.unesco.org/images/0013/001321/132114e.pdf

Edvinsson L. and Malone M. S. (2001). “Intellectual capital.” PWN Scientific Publisher, Warsaw.

Fazlagić, Jan, and Erkol, Arif (2017). "Images of Intellectual Capital,” Cambridge Scholars, Cambridge.

Florin, J. and Schultze, W., (August 2000). "Social capital and fundability of high potential new ventures," Presented at the Academy of Management Meetings, Toronto

Guthrie, James, and Petty, Richard (2000). "Intellectual capital: Australian annual reporting practices," Journal of Intellectual Capital, (1)3:241-251

Guthrie, J. (2001). “The management, measurement and the reporting of intellectual capital,” Journal of Intellectual Capital, (2):24-41.

Grant, Robert M. (1991), "The Resource-Based Theory of Competitive Advantage: Implications for Strategy Formulation," California Management Review, 33(3): 114-135.

Hamel, Gary, and Heene, Aimé (1994). "Competence-Based Competition." The Strategic management series. Wiley, Chichester; New York

Heizer, Jay, and Render, Barry (2008). “Operations Management,” $8^{\text {th }}$ ed., PrenticeHall, Inc., New Jersey.

Hilali, Sherbini (2011). "Management, Measurement, and Development of Intellectual Capital as part of Knowledge Management in Higher Education Institutions," Journal of Specific Education Research, Mansoura University, Egypt, No. 22.

Hill, C. W. \& Jones, G. R., (1989). "Strategic management of an integrated approach," $4^{\text {th }}$ ed., New York: Houghton Mifflin Co.

Hill, C. W. \& Jones, G. R., (2010). “Strategic Management Theory: An Integrated Approach,” 9 ${ }^{\text {th }}$ ed, South-Western Cengage Learning.

Huysman, M. H., and Wit, D. H (2002). "Knowledge Sharing in Practice.” Springer Science \& Business Media.

Inter, Christopher D., and Larcker, David F. (2003). "Coming up short on nonfinancial measurement." Harvard Business Review, 81(11):88-95. Available at www.hbr.org.

Jadalrab, Sayed M. (2006). "Managing Intellectual and Knowledge Resources in Modern Business Organizations." Cairo, Al-Ashry Press

Köper, Johannes, and Zaremba, Hans J. (2000). “Quality Management and Qualification Needs.” Springer Science \& Business Media.

Lambin, Jean-Jacques (1998). “Marketing Stratégies,” Paris. 
Luthans, F. et al. (2004). "Positive psychological capital: Beyond human and social capital." Business Horizons, (47)1:45-50.

Najm, Aboud (2016). “The Intangibles Management: Management Immeasurable.” Al-Yāzūrī.

Nedjema Abbas (2016). “The Role of Intellectual Capital in Achieving Organizational

Ordóñez de Pablos, P. and Edvinsson, L. (Eds) (2015). "Intellectual Capital in Organizations. Non-Financial Reports and Accounts," Routledge, New York.

Ousama, A. et al (2014). "Intellectual Capital and Islamic Banks Performance in the GCC," $6^{\text {th }}$ European Conference on Intellectual Capital, ECIC.

Osinski, M. et al (2017). "Methods of evaluation of intangible assets and intellectual capital," Journal of Intellectual Capital, (18)3:470-485.

Porter, M. (1985). Competitive Advantage: Creating and Sustaining Superior Performance, New York, The Free Press.

Porter, M. (1993). “Competitive Advantage of Nations”, USA, Harvard Business Review, Inter-edition

Roos, J., Roos, G., Edvinsson, L. and Dragonetti, N.C. (2001), Capital Intelectual: El valor intangible de la empresa, Paido's, Barcelona.

Rowley, Daniel James and Herbert Sherman (2004). "From Strategy to Change: Implementing the Plan in Higher Education," John Wiley and Sons.

Sanjoy, Bose and Thomas, Keith (2007). "Applying the balanced scorecard for better performance of intellectual capital,” Journal of Intellectual Capital, (8)4:653665.

Schultz, Theodore (1961). "Investment in Human Capital." American Economic Review, (51)1:1-17.

Suarez, A. and Moreira, R. S (2006). "The Role of Usability in the Competitiveness of Higher Education Institutions," An International Conference: Applied Computing, San Sebastian, Spain, pp 25-28.

Sullivan. P, (2001). "Value-driven Intellectual capital: How to convert intangible corporate Assets into market value." Wiley, New York.

Stewart, T.A, (February 19, 1996). "The coins in the knowledge bank," Fortune.

Stewart, T.A., (1999). "Intellectual Capital: The new wealth of organization,” Doubleday-Currency, New York.

Stewart, T. A. (2007). “The Wealth of Knowledge.” Crown Publishing Group.

Stewart, T. A. (2010). "Intellectual Capital: The new wealth of organization,” Crown Publishing Group

Ulrich, D. (1998). "Delivering results: A new mandate for human resource professionals.” Boston: Harvard Business School Press.

UNESCO, (2003). "Communiqué of the ministerial roundtable on 'Towards Knowledge Societies'." Paris: UNESCO.

Viedma, J. M., and Cabrita, M. R. (2012). "Entrepreneurial excellence in the knowledge economy. Intellectual capital benchmarking systems.” Palgrave Macmillan, London.

Wall, A., Kirk, R. and Martin, G. (Oct 20, 2003). “Intellectual Capital: Measuring the Immeasurable?"p.15, Elsevier. 